\title{
Bacterial Community Is Affected by Locations and Time Rather Than Potato Varieties but Streptomyces spp. Are Related to Potato Varieties
}

\author{
Geon Seung Lee ${ }^{1,+}$, Mahesh Adhikari ${ }^{2,+}{ }^{\mathbb{D}}$, Jae E. Yang ${ }^{3} \mathbb{D}$, Hyuck Soo Kim ${ }^{3}$, Kyu Suk Han ${ }^{4}$, Kean-Soo Ha ${ }^{4}$ \\ and Duck Hwan Park $1,2, *$ D
}

1 Interdisciplinary Program in Smart Agriculture, Kangwon National University, Chuncheon 24341, Korea; kunseung725@hanmail.net

2 Applied Biology Program, Division of Bioresource Science, Kangwon National University, Chuncheon 24341, Korea; maheshadhikari@kangwon.ac.kr

3 Department of Biological Environment, Kangwon National University, Chuncheon 24341, Korea; yangjay@kangwon.ac.kr (J.E.Y.); kimhs25@kangwon.ac.kr (H.S.K.)

4 Potato Research Institute, Gangwon-do Agricultural Research \& Extension Services, Gangneung 25437, Korea; kyusuk321@korea.kr (K.S.H.); redclover@korea.kr (K.-S.H.)

* Correspondence: dhp@kangwon.ac.kr; Tel.: +82-33-250-6432; Fax: +82-33-259-5558

+ Joint first authors.

Citation: Lee, G.S.; Adhikari, M.; Yang, J.E.; Kim, H.S.; Han, K.S.; Ha, K.-S.; Park, D.H. Bacterial

Community Is Affected by Locations and Time Rather Than Potato

Varieties but Streptomyces spp. Are Related to Potato Varieties. Diversity 2021, 13, 659. https://doi.org/ $10.3390 / \mathrm{d} 13120659$

Academic Editors: Ipek Kurtboke, Milko A. Jorquera and

Jacquelinne Acuña

Received: 27 October 2021

Accepted: 8 December 2021

Published: 11 December 2021

Publisher's Note: MDPI stays neutral with regard to jurisdictional claims in published maps and institutional affiliations.

Copyright: (c) 2021 by the authors. Licensee MDPI, Basel, Switzerland This article is an open access article distributed under the terms and conditions of the Creative Commons Attribution (CC BY) license (https:// creativecommons.org/licenses/by/ $4.0 /)$

\begin{abstract}
Improved knowledge and a better understanding of the functions of bacterial communities are vital for effective crop disease management. This study was conducted to study a bacterial community's relationship with the common scab in four different potato varieties (Dejima, DJ; Atlantic, DS; Seohong, SH; Haryeong, HY) at two different locations (Gangneung and Chuncheon) and spatial locations (rhizosphere and furrow) at two different times (preharvest and postharvest). In addition, metagenomic sequencing was performed by extracting genomic DNA from soil samples to observe the dominant bacterial microbes and disease severity of the common scab in all the tested varieties in spatial location and time. The results suggest that the most dominant bacterial phyla in all the soil samples were Proteobacteria, Acidobacteria, and Bacteroidetes. Additionally, Streptomyces spp. were found to be more abundant in the susceptible variety (DJ) than in other varieties (DS, $\mathrm{SH}$, and $\mathrm{HY}$ ). Interestingly, bacterial communities were found to be more diverse across the two different geographical locations, spatial locations, and harvesting times, rather than the variety of potato, according to PCoA analysis. There were no interlinked changes in bacterial communities among the varieties. Moreover, the 14 most dominant bacterial genus correlation networks with Streptomyces spp. suggested that there was a significant positive and negative correlation to some extent. Alpha and beta diversity results clearly indicated that the possible reason for differences in bacterial communities might have been due to the different spatial locations, in comparison with varieties, which suggests that there was no significant correlation between bacterial community richness and diversity among the varieties.
\end{abstract}

Keywords: diversity; metagenomics; Streptomyces spp. spatial location; variety

\section{Introduction}

Potato (Solanum tuberosum L.) is the fourth largest staple food crop in the world and provides nutritionally beneficial additives (FAO STAT) [1]. Microorganisms play a pivotal role in soil environments. Shifts in microbial populations often indicate changes in the soil environment. Soil microorganisms are the most active components of soil decomposition systems [2]. Recently, many researchers have focused on soil microbial communities to improve their application and promote plant health [3]. Currently, soil microbiome analysis via metagenomics sequencing has been introduced to assess the resistivity or susceptibility of plants to diseases [4]. Taking these factors into consideration, 
soil microbiome structure and functioning can determine plant-pathogen interactions under natural field conditions [5].

Common scab on potatoes is a bacterial disease caused by Streptomyces spp. [6]. Symptoms include lesions on the surface of roots and tubers, leading to huge economic losses. Eradication of this bacterial disease is difficult once it is present in the soil [7]. Common scab disease is influenced by various environmental factors, such as $\mathrm{pH}$, soil moisture, and microorganisms [8]. Management of this bacterial disease is difficult because of the diversity of severity in field soils $[9,10]$. To address this issue, a better understanding of bacterial community structure and diversity in rhizospheric soil and its association with Streptomyces spp. is essential.

The technique of controlling disease by irrigation water treatment during tuber formation has been previously described as a method for controlling common scab. In an early study, irrigation water treatment was effective in reducing the disease in cases of susceptible varieties to common scab [11] whereas Larkin et al. 2011 [12] reported an increase in disease production when water treatment was too frequent. In addition, it has been reported that increased moisture in the soil is related to outbreaks of netted scabs [13]. The change in soil $\mathrm{pH}$ by acidic amendments can be effective, as these pathogens are generally inhibited at a low soil $\mathrm{pH}$ [14]. However, the emergence of species that tolerate lower $\mathrm{pH}$ than S. scabies, such as S. acidiscabies and S. turgidiscabies $[15,16]$, may adversely affect other crops during rotation. Although the treatment of fumigants in the soil is a means of controlling several soil diseases, including common scab [17], this method is limited due to high cost and environmental pollution issues. Previous studies have reported that rotation using canola and rye had an inhibitory effect on plant disease $[18,19]$. Common scab can be reduced by seed disinfection and planting disease-free seeds, the main purpose of which is to control fungal and viral diseases [8], but the effect on soil diseases will be limited.

Biological control is an alternative to the aforementioned control methods. Hence, many studies on the biological control of common scab have been conducted using antagonistic microorganisms, such as Streptomyces, Pseudomonas, and Bacillus [20,21]. However, treatment with these antagonistic microorganisms often leads to inconsistent effects in the field [22] as biological control methods are difficult to apply due to the complexity of the interaction between the soil environment and soil microbial community [23]. Therefore, if the diversity and alteration of the microbial community in the disease-occurring soil before and after treatment with antagonistic microorganisms can be predicted, the biological control effect on soil diseases, such as common scab, by these antagonistic microorganism treatments can be accelerated. Fortunately, the microbial community and diversity in soil by metagenome analysis was performed recently. For example, identifying the characteristics of microbial communities in soil infected with Ralstonia solanacearum, constructing soil microbial communities using biofertilizers, using these to control Fusarium wilt, and deciphering microbial communities in disease-suppressive soils [24,25].

Metagenomics sequencing is a recently developed technique that provides holistic information on soil bacterial diversity. Recently, this sequencing approach has helped to identify the possible role of the microbial community in soil $[26,27]$. In addition, metagenomic sequencing analysis helps to clarify the potential functional role of microbial communities in soil [28]. Metagenomics sequencing helps to identify the bacterial diseases invasion which are not noticeable until the total loss of the plant [29]. In addition, nonnotable bacterial pathogen causes severe yield losses as they are able to thrive in soil for prolonged periods of time without the presence of the host. Regarding this, metagenomics sequencing analysis can detect the presence or absence of pathogens in soils [30]. This sequencing technology has shown a step-way change in facilitating the characterization of microbiota [31,32]. Previous studies on the diversity of microbes were mainly based on the selective media technique for morphological and molecular identification. Media-based techniques lead to biasness in culturing and identifying microbes. To cope with such limitations, metagenomics sequencing is a better approach to study the diversity of soil microbes and how their functional roles in soil can directly or indirectly affect plant health. The 
purpose of our study was (1) to analyze the bacterial community, such as the diversity and abundance of microbes according to the season and influence of potato cultivation in potato croplands, by performing a metagenome analysis of the microbiome and (2) detection for any correlation of common scab with dominant bacterial genus. Therefore, microbial communities in the soil before and after potato cultivation, and in the rhizosphere and bulk soil, were analyzed from the repeated potato cultivation in Gangneung site and rotation of potato with Brassicaceae crops (cabbage in spring season and radish in autumn season) in Chuncheon where the distribution patterns of common scab pathogens were shown.

\section{Materials and Methods}

\subsection{Field Site Description}

Experimental field sites were designed at the Gangneung Potato Research Center and Chuncheon-si Agricultural Research and Extension Services, Gangwon-do, Republic of Korea (Supplementary Figure S1). Susceptible (Daeji and Daeseo) and resistant (Seohong and Haryeong) varieties of potato were cultivated in both research centers. The field of Gangneung was divided into 12 different plots $10 \mathrm{~m}$ in width and $15.7 \mathrm{~m}$ in length. Gangneung field has been used continuously cultivated with potato since more than 10 years. A randomized complete block design (RCBD) was performed in three different plots for each variety (resistant and susceptible). Twenty seeds of each variety of potatoes were sown manually at the intervals of $25 \mathrm{~cm}$ on each plot on 29 April 2020. In the field of Chuncheon, 12 plots were divided into two ridges with a width of $6 \mathrm{~m}$ and a length of $50 \mathrm{~m}$. Chuncheon field has been used for potato cultivation in spring season while cabbage or radish crop in autumn season. Seeds were sown manually similar to the Gangneung field on 8 May 2020. Herbicides and pesticides were not applied during the growing phase of potatoes. However, weeds were manually removed. Environmental parameters such as the average, minimum, and maximum temperatures and precipitation were recorded for a week in both the Gangneung and Chuncheon fields (Supplementary Table S1). The climate of both fields was assessed by the Korea Meteorological Administration (https: / / www.weather.go.kr/weather/main.jsp, accessed on 8 March 2020).

\subsection{Soil Sampling and Harvesting of Potato}

Preharvest soil sampling was performed on 29 April 2020, and 8 May 2020, in the Gangneung and Chuncheon fields, respectively. Soil samples were collected using a sterilized auger at a depth of $20-30 \mathrm{~cm}$ in each ridge. Soil samples were collected around the potato roots and tubers, placed in sterilized polythene zipper bags, and then brought to the laboratory. The soil samples were then dried for five days, after which large roots and pebbles were removed and sieved through an autoclaved-sterilized brass sieve with a $2 \mathrm{~mm}$ aperture size and stored at $4^{\circ} \mathrm{C}$ until use.

\subsection{Soil Chemical Properties Determination}

Soil chemical properties such as $\mathrm{pH}$, electrical conductivity (EC), soil organic matter (SOM), and exchangeable cations $\left(\mathrm{Ca}^{2+}, \mathrm{K}^{+}, \mathrm{Mg}^{2+}, \mathrm{Na}^{+}\right)$were analyzed (Table 1). Soil $\mathrm{pH}$ and EC were measured in a 1:5 ratio of soil to ionized water using a digital $\mathrm{pH}$ meter (Orion Star tm A215 pH/Conductivity meter) [33]. SOM was determined using the Walkey and Black method with acid-wet oxidation, and the dichromate method [33]. Exchangeable cations in the soil were measured using an ICP-OES iCAP 6300Duo (Thermo Fisher Scientific, Waltham, MA, USA) instrument. 


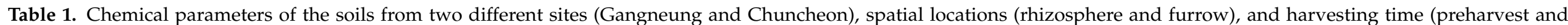
postharvest).

\begin{tabular}{|c|c|c|c|c|c|c|c|c|}
\hline \multirow{2}{*}{ Field Sites } & \multirow{2}{*}{$\begin{array}{c}\text { Harvest Time } \\
\text { (Spatial Location) }\end{array}$} & \multirow{2}{*}{$\mathrm{pH}$} & \multirow{2}{*}{$\begin{array}{c}\text { EC } \\
\left(\mathrm{dsm}^{-1}\right)\end{array}$} & \multirow{2}{*}{$\begin{array}{c}\text { SOM } \\
\left(\mathrm{gkg}^{-1}\right)\end{array}$} & $\mathrm{Ca}^{2+}$ & $\mathrm{K}^{+}$ & $\mathrm{Mg}^{2+}$ & $\mathrm{Na}^{+}$ \\
\hline & & & & & \multicolumn{4}{|c|}{$\left(\mathrm{Cmolkg}^{-1}\right)$} \\
\hline \multirow{3}{*}{ Gangneung } & Preharvest & $6.05 \pm 0.27^{a b}$ & $1.13 \pm 0.43^{a}$ & $11.15 \pm 0.82^{a}$ & $7.74 \pm 0.18^{a}$ & $0.18 \pm 0.03^{a}$ & $2.54 \pm 0.13^{a}$ & $0.16 \pm 0.01^{a}$ \\
\hline & $\begin{array}{l}\text { Postharvest } \\
\text { (Rhizosphere) }\end{array}$ & $5.64 \pm 0.09^{a}$ & $0.59 \pm 0.13^{a b}$ & $13.94 \pm 1^{b}$ & $5.68 \pm 0.37^{b}$ & $0.12 \pm 0.02^{\mathrm{a}}$ & $0.6 \pm 0.03^{b}$ & $0.19 \pm 0.01^{\mathrm{a}}$ \\
\hline & $\begin{array}{l}\text { Postharvest } \\
\text { (Furrow) }\end{array}$ & $6.37 \pm 0.21^{\mathrm{a}}$ & $0.35 \pm 0.02^{b}$ & $14.83 \pm 2.37^{a}$ & $5.66 \pm 0.14^{b}$ & $0.1 \pm 0.01^{b}$ & $1.61 \pm 0.07^{b}$ & $0.17 \pm 0.02^{a}$ \\
\hline \multirow{3}{*}{ Chuncheon } & Preharvest & $6.43 \pm 0.28^{b}$ & $4.23 \pm 1.56^{\mathrm{a}}$ & $19 \pm 1.34^{\mathrm{a}}$ & $5.52 \pm 1.03^{a}$ & $1.12 \pm 0.77^{a}$ & $1.35 \pm 0.24^{\mathrm{a}}$ & $0.54 \pm 0.41^{a}$ \\
\hline & $\begin{array}{l}\text { Postharvest } \\
\text { (Rhizosphere) }\end{array}$ & $7.36 \pm 0.04^{\mathrm{a}}$ & $0.53 \pm 0.06^{a}$ & $25.72 \pm 5.47^{a}$ & $3.83 \pm 0.34^{\mathrm{ab}}$ & $0.11 \pm 0.02^{\mathrm{a}}$ & $0.83 \pm 0.03^{a}$ & $0.16 \pm 0.01^{\mathrm{a}}$ \\
\hline & $\begin{array}{l}\text { Postharvest } \\
\text { (Furrow) }\end{array}$ & $7.23 \pm 0.06^{\mathrm{a}}$ & $0.34 \pm 0.03^{a}$ & $24.99 \pm 2.9^{a}$ & $3.18 \pm 0.24^{b}$ & $0.11 \pm 0.01^{a}$ & $0.81 \pm 0.01^{b}$ & $0.15 \pm 0.01^{a}$ \\
\hline
\end{tabular}

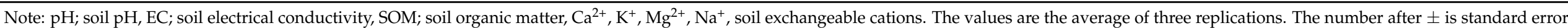
The values with same alphabetic letters are not significantly different at $p<0.05$. 


\subsection{Soil DNA Extraction, PCR Amplification and Gene Expression}

Total DNA was extracted using a FAST DNA ${ }^{\mathrm{TM}}$ Spin Kit for soil following the FastPrep system MP Bio protocol (MP Biomedicals, Seoul, Korea). The soil total DNA was adjusted to a concentration of $100 \mathrm{ng} / \mu \mathrm{L}$, and qPCR was performed using a 96-well plate in the Step One Plus Real-Time PCR System (Applied Biosystems, Foster City, CA, USA). The DNA, each 10 pmol primer, and $10 \mu \mathrm{L}$ Real-Time PCR Master Mix (Elpis Biotech, Daejeon, Korea) were mixed and adjusted to a total volume of $20 \mu \mathrm{L}$. The results were derived through normalization using the $t x t A B C t$ value and $16 \mathrm{~S}$ rRNA Ct value. The extracted DNA was stored at $-70{ }^{\circ} \mathrm{C}$ in a deep freezer for PCR amplification and sequencing. Quantitative polymerase chain reaction (qPCR) amplification was performed after the extraction of total DNA from the soil samples. The expression levels of the 16S rRNA gene and the thaxtomin toxin biosynthesis gene $t x t A B$ in the extracted total DNA were detected by qPCR. Txt $A B$ amplification primers were StrepF (5'-GCAGGACGCTCACCAGGTAGT-3') and StrepR (5'-ACTTCGACACCGTTGTCCTCAA- $\left.3^{\prime}\right)$. The $16 \mathrm{~S}$ rRNA amplification primers 515F (5'GGACTACVSGGGTATCTAAT- $3^{\prime}$ ) and 806R (5'-GTGCCAGCMGCCGCGGTAA-3') were used as the target gene 292bp [34]. Primers StrepF (5GCAGGACGCTCACCAGGTAGT-3) and StrepR ACTTCGACACCGTTGTCCTCAA-3') were used for $t x t A B$ amplification [35].

\subsection{Sequencing Data and Diversity Analysis}

Raw sequences obtained from PCR amplicon sequencing were processed and analyzed in the following three steps: data trimming, taxonomy assignment and normalization, and diversity analysis. Briefly, in data trimming, raw sequences were filtered through FastQC from the software fastqc v0.11.2 (https:/ / www.bioinformatics.babraham.ac.uk/ projects/ fastqc, accessed on 25 September 2021). Forward and reverse directions of FastQC files were assimilated using vsearch v2.10.3 (https:/ / www.github.com/torognes/vsearch, accessed on 25 September 2021) [36]. This process helped remove low-quality or unassembled sequences with $>97 \%$ similarity that could be clustered into operational taxonomic units (OTUs). The OTU for each representative sequence was constructed using QIME (Quantitative Insights into Molecular Ecology) software package (version 1.17 [37] to annotate the taxonomic information for each representative sequence. Alpha diversity, including Chao1, OTUs, and Shannon indices, were calculated with QIIME to assess the bacterial species richness and diversity for each soil sample. For beta diversity patterns of the bacterial communities, principal coordinate's analysis ( $\mathrm{PCoA})$ was performed using unweighted UniFrac [38].

\subsection{Disease Severity Analysis}

Common scab severity in potato plants cultivated in Gangneung and Chuncheon was recorded. The disease incidence for each variety was measured as the average value of three replications. Grading of disease severity was performed on a $0-4$ grading scale in accordance with the ratio of scab symptoms on the surface of potato tubers $(0=0 \%-1 \%$, $1=1 \%-10 \%, 2=10.1 \%-20 \%, 3=20.1 \%-30 \%$, and $4=$ more than $30.1 \%)$. The disease severity was calculated using the following Equation:

Disease severity $(\%)=\frac{\sum \text { Grade } \times \text { number of potatoes according to grade }}{\text { Total number of potatoes } \times 5(\text { number of grade })} \times 100$

\subsection{Statistical Analysis}

Statistical analysis was carried out on the datasets using the basic functions of 'Excel v. 2016 and software ' $R$ ' studio $v 4.03$ '. The analysis of variance (ANOVA) was calculated using the basic package 'stats v4.03', and the LSD (Least Significant Difference) test was determined with the Bonferroni method using ' $R$ package agricolae v1.3-3'. In addition, the heat map was also constructed using ' $R$ package gplot v3.1.0'. A correlation network of bacterial communities in the soil was generated using 'cytoscape v3.8.0'. 


\section{Results}

\subsection{Environmental Parameters and Soil Chemical Properties}

The environmental parameters of the studied locations before and after harvesting are listed in Supplementary Table S1. The mean temperature difference in Gangneung was $2.8^{\circ} \mathrm{C}$. However, the deviation in mean temperature was significantly different in Chuncheon $\left(8.8^{\circ} \mathrm{C}\right)$. In addition, the temperature differences after postharvest among the two study sites were different (Supplementary Table S1). The chemical properties varied among the studied soil samples. The $\mathrm{pH}$ of preharvest rhizospheric soils at the Gangneung site showed a low $\mathrm{pH}$, while postharvest furrow soil showed a slightly higher $\mathrm{pH}$ (Table 1). The $\mathrm{pH}$ of preharvest and postharvest soils from the Chuncheon site soils was higher than that of the Gangneung soil. The EC of postharvest soil samples was lower at both sites (Table 1). SOM content was higher in the postharvest soil samples (Table 1). Among the exchangeable cations $\left(\mathrm{Ca}^{2+}, \mathrm{K}^{+}, \mathrm{Mg}^{2+}\right.$, and $\left.\mathrm{Na}^{+}\right), \mathrm{Ca}^{2+}, \mathrm{K}^{+}$, and $\mathrm{Mg}^{2+}$ were lower in the postharvest soil samples (Table 1 ).

\subsection{Composition of Dominant Bacterial Community and Their Similarities}

The dominant bacterial group was classified at the phylum level from pre- and postharvest soils (rhizosphere and furrow) in Gangneung and Chuncheon (Supplementary Figure S2). The dominant phyla in both study sites were similar. However, the phylum Armatimonadetes was only abundant in the Gangneung soils, and Halanaerobiaeota and Patescibacteria were dominant in the Chuncheon soils. In general, Proteobacteria was the most abundant bacterial phylum detected in the soils at both study sites. When comparing the two sites, we could not observe a difference in bacterial abundance in Gangneung soils with respect to harvesting time (Supplementary Figure S2). However, a higher abundance was observed in the rhizospheric soil of Chuncheon. The results suggest that the Halanaerobiaeota in Chuncheon and the Bacteroidetes in both sites were decreased in postharvest soil samples.

With respect to four different factors: site, spatial location, harvesting time, and variety, the top 20 dominant bacterial genera were categorized. The results indicated that 10 taxa genera were common in preharvest soil samples from both studied sites. Among them, the most dominant genera were Flavobacterium, Sphingomonas, Pseudarthrobacter, and Pyrinomonadaceae, RB41. In contrast, Halocella and Pseudomonas were found at higher ratios (Figure 1A,B). Furthermore, differences in the bacterial communities between preharvest soil samples and rhizospheric soil samples at both sites were also investigated. A total 13 common genera were detected in both the soil samples. Candidatus, Nitrocosmicus, and Pseudolabrus had higher ratios in rhizospheric soil (Figure 1A,C). At the Chuncheon site, Rhodanobacter, and Nitrosomonadaceae MND1 were the most dominant organisms observed (Figure 1B,D). In addition, 12 and 10 bacterial genera (Figure 1A,B,E,F) were recovered from preharvest and furrow soil samples from Gangneung and Chuncheon, respectively. Moreover, the dominance of bacterial genera was also investigated in soils of different cultivated varieties. Candidatus and Nitrocosmicus were higher in the DS variety. In the case of soil samples from Chuncheon, Pyrinomonadaceae RB41 was the most dominant among all varieties (Figure 1E,F).

Principal coordinate analysis (PCoA) was performed to visualize the similarities of the bacterial communities in all soil samples. The results obtained from PCoA suggest that the bacterial communities in Gangneung and Chuncheon were not similar (Figure 2). Interestingly, bacterial communities from rhizospheric and furrow soils were clustered during preharvest in Chuncheon (Figure 2). In addition, all varieties were clustered together in the rhizospheric soils of Gangneung. 


\section{Gangneung}

\section{Chuncheon}
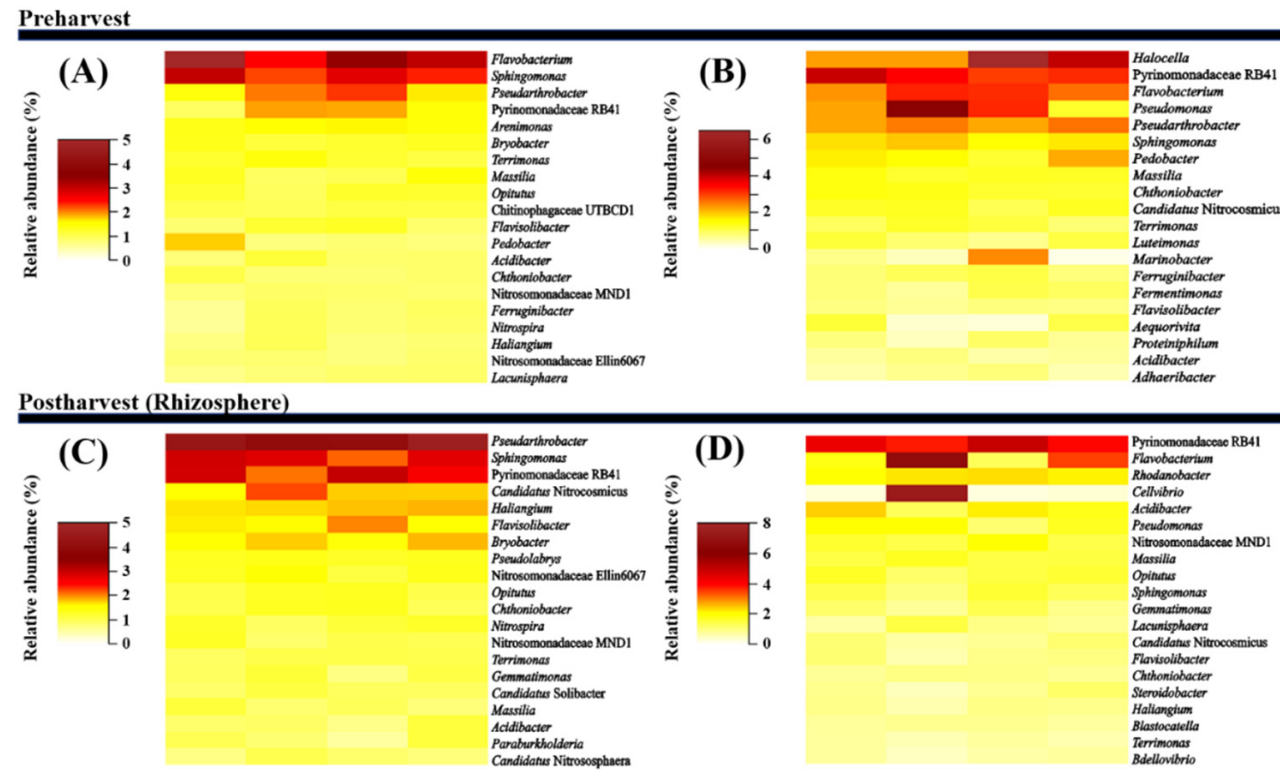

Postharvest (Furrow)
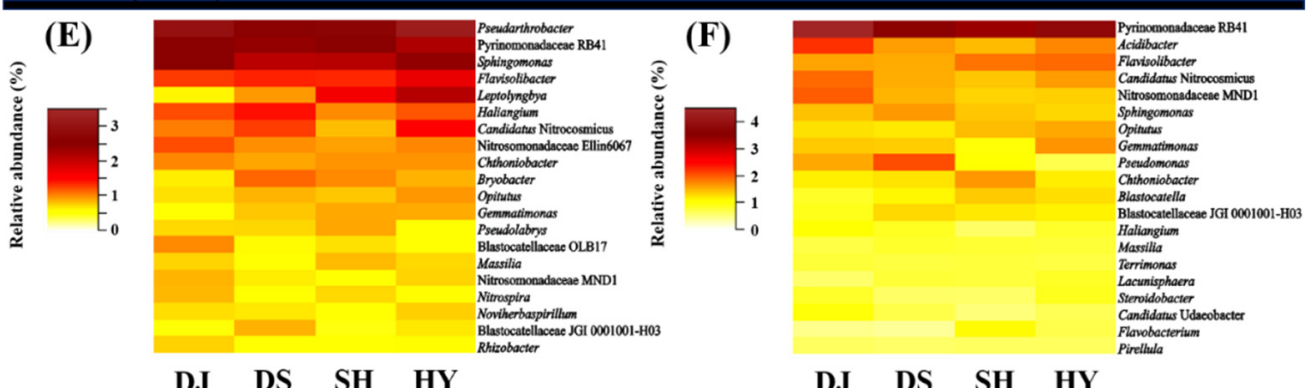

Figure 1. Heat map of relative abundance of dominant genus. The relative abundance at the genus level was analyzed according to the sites, spatial locations, harvest time and varieties. The color of each heat map block was visualized as the average value of three replica $(\mathbf{A}, \mathbf{B})$ dominant bacterial genus before harvesting of potato in Gangneung and Chuncheon field soils; (C,D), dominant bacterial genus obtained from rhizospheric soils of harvested potato field of Gangneung and Chuncheon; (E,F) dominant bacterial genus obtained from furrow soils of harvested potato field of Gangneung and Chuncheon. Note: (DJ: Daeji, DS: Daeseo, SH: Seohong and HY: Haryoung).

\subsection{Bacterial Diversity}

Bacterial diversity was analyzed according to the location and harvesting time (Supplementary Figure S3). The Chao1 index (species richness) in preharvest soils at both locations was not significantly different. The Chao1 index was higher in postharvest soil samples from the rhizosphere and furrows (Supplementary Figure S3). There was no significant difference in the Chao1 index between preharvest and rhizosphere soils, but it was higher in furrow soils of Chuncheon. The OTUs of the soil samples were found to be similar to those of Chao1 in both locations (Supplementary Figure S3). The Shannon index from the Gangneung soils did not differ with respect to location and harvesting time. Preharvest and rhizospheric soils had a higher Shannon index. 


\section{Unweighted UniFrac}

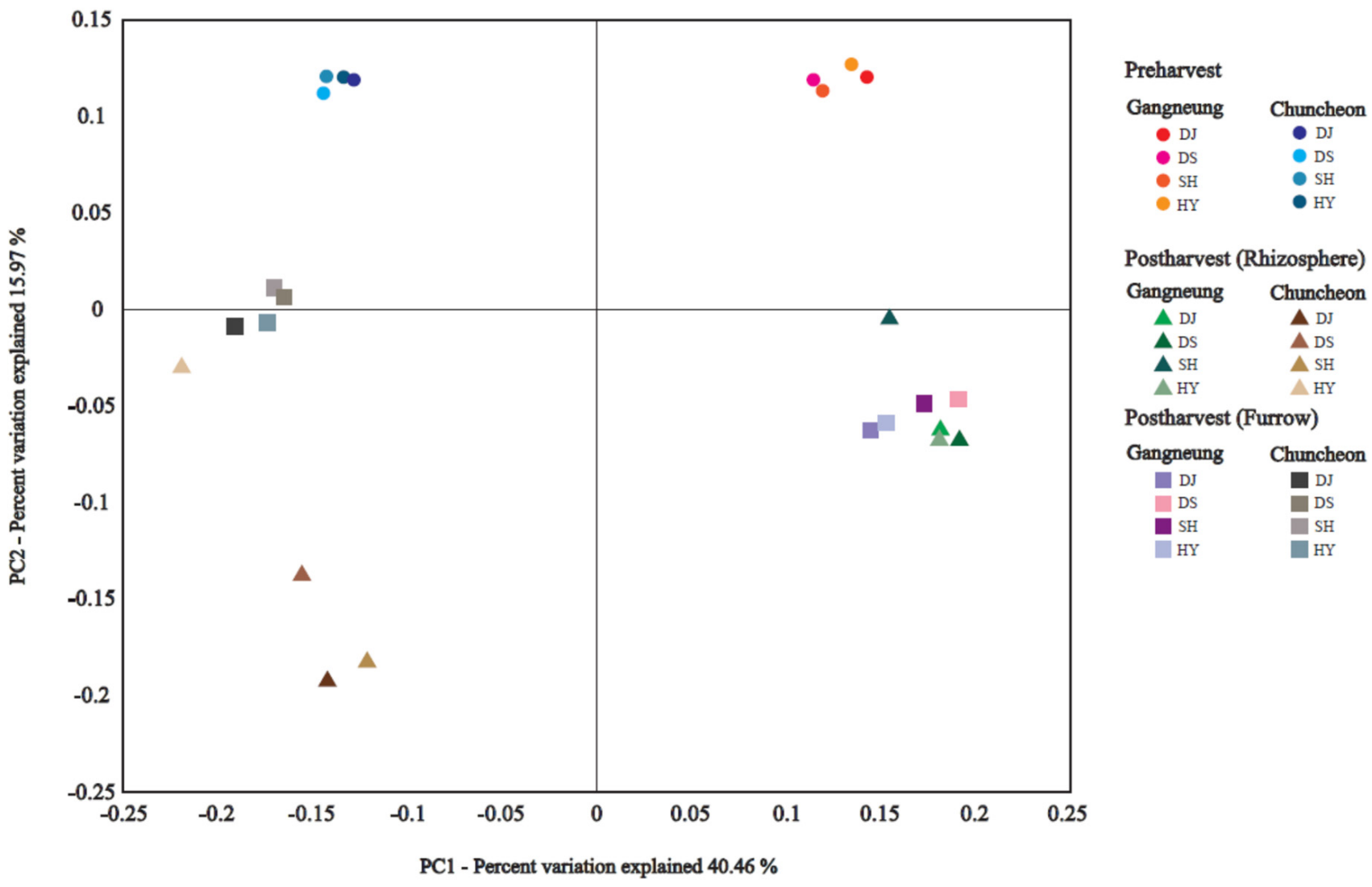

Figure 2. Analysis of variation of bacterial communities using PCoA on the basis of Unweighted UniFrac. PCoA analysis was carried out according to the sites (Gangneung and Chuncheon), spatial locations (rhizosphere and furrow), harvest time (preharvest and post-harvest) and varieties (DJ, DS, SH, HY). Note: (DJ: Daeji, DS: Daeseo, SH: Seohong and HY: Haryoung).

Furthermore, bacterial diversity was compared in the cultivated soils of different potato varieties. The Chao1 index in all varieties (except DS cultivated in Gangneung) was higher in the postharvest rhizosphere and furrow than in preharvest soil samples (Supplementary Figure S4a). Chao1 and OTUs were observed to be different in samples from all varieties. No significant difference was observed in DJ and HY based on location and harvesting time in Chaol and OTUs. The OTUs of DS were lower in rhizospheric soil during preharvest, but higher in furrow soils. The Chao1 and OTUs of SH from the Chuncheon site were similar to those of Gangneung site soils (Supplementary Figure S4b). Moreover, there was no significant difference in the Shannon index between the varieties based on location and harvesting time.

\subsection{Relative Abundance of Streptomyces spp. in Soil and Its Severity in Potato Varieties}

We observed a difference in the relative abundance of Streptomyces spp. based on the spatial location and harvesting time at both study sites (Figure 3). The abundance of Streptomyces spp. in the preharvest and furrow soils of Gangneung was not significantly different. Notably, the abundance of Streptomyces spp. was high in the rhizospheric soil where potato tubers were grown in both sites. 


\section{Gangneung}

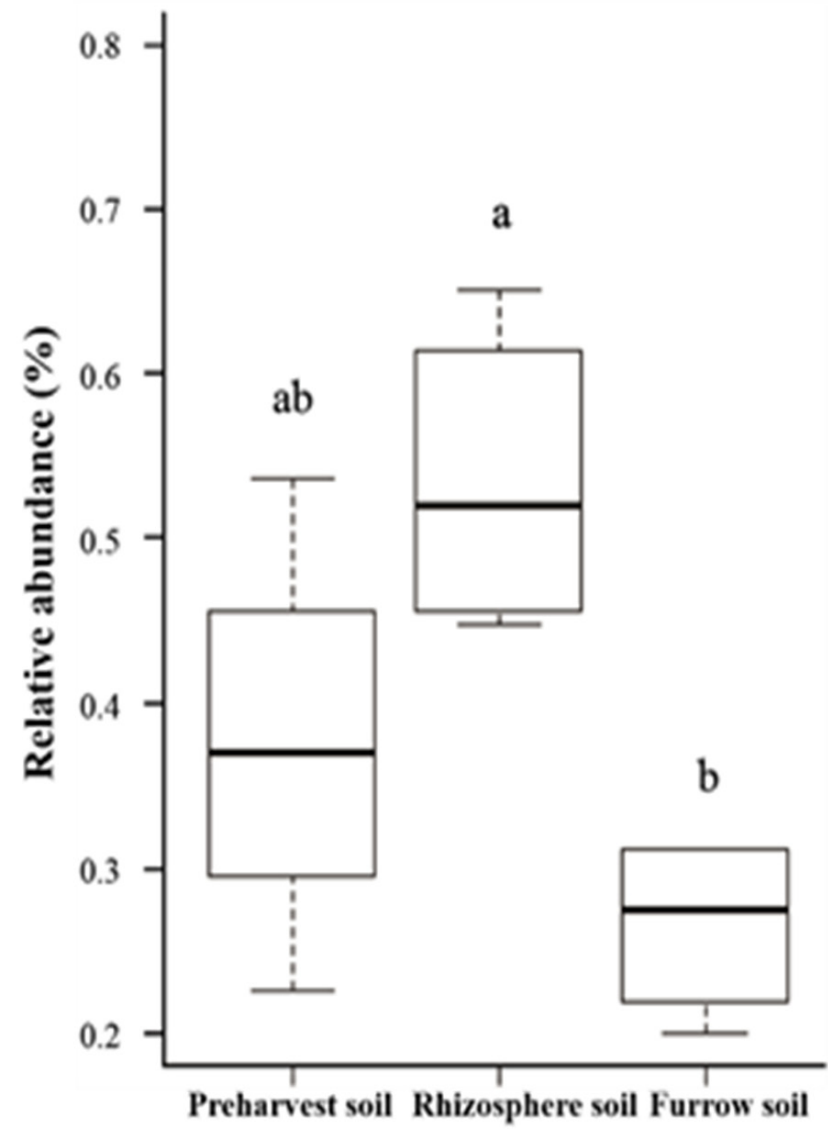

\section{Chuncheon}

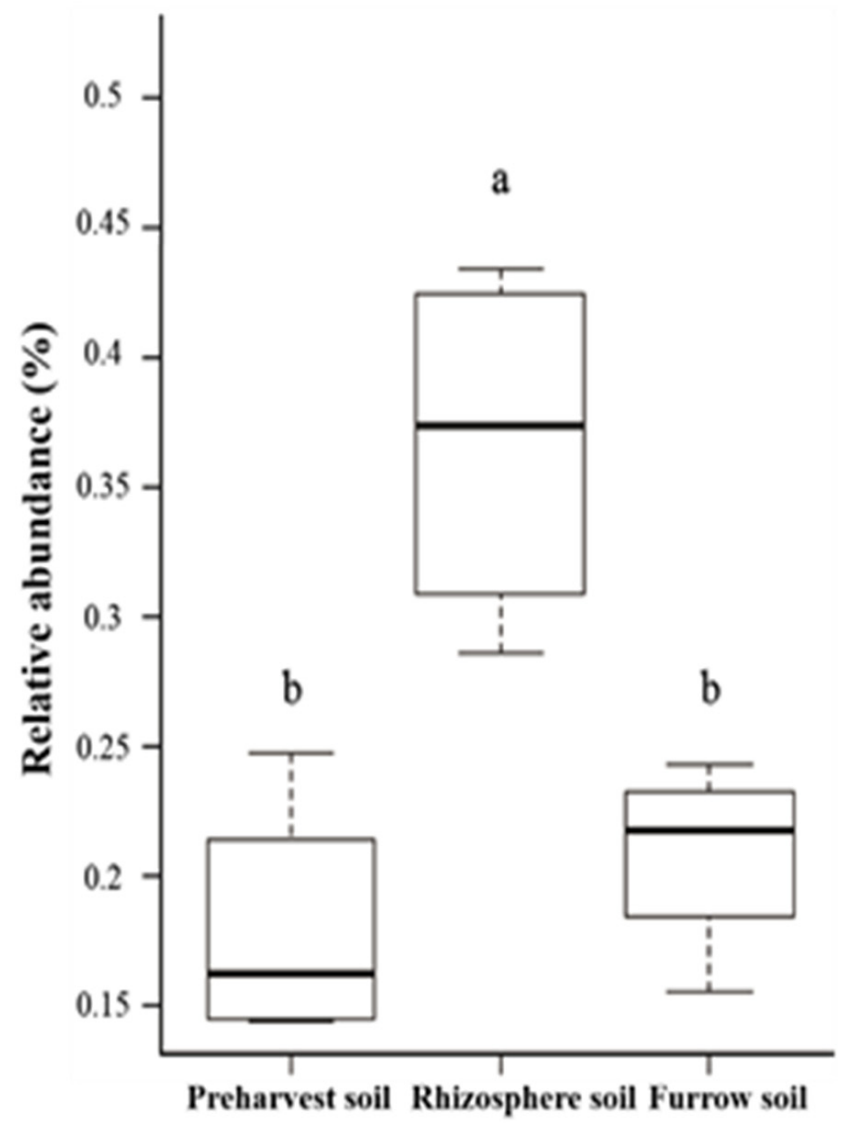

Figure 3. Comparison of relative abundance of Streptomyces spp. based on sites (Gangneung and Chuncheon), spatial locations (rhizosphere soil and furrow soil) and harvest time (preharvest soil). Each box plot is represented with 12 average values. The values with same alphabetic letters are not significantly different at $p<0.05$. Note: Preharvest soil; before harvesting of potato. Rhizophere and furrow soil; spatial locations.

The results confirmed that the relative abundance of Streptomyces spp. and severity was higher in rhizospheric soils at both sites (Figure 4A-D). Further comparisons were made for disease severity between the potato varieties and the ratio of Streptomyces spp. in the rhizospheric soils of Gangneung and Chuncheon. Likewise, the level of $t x t A B$ coding biosynthesis of thaxtomin gene expression to confirm the presence of Streptomyces spp. based on the location and harvesting time was also performed (Figure $4 \mathrm{E}, \mathrm{F}$ ). The results suggest that disease severity was high in susceptible varieties cultivated in Gangneung. Although the relative abundance of Streptomyces spp. was high in the resistance variety, the disease severity was found to be low (Figure 4A). Disease severity patterns were similar in Chuncheon and Gangneung, except for the DJ variety (Figure 4B). Surprisingly, we could not find a significant difference in disease severity between the resistant and susceptible varieties. However, $t x t A B$ expression was observed at both studied locations in the preharvesting soil samples. According to the results, the expression level of $t x t A B$ in the DJ and HY varieties was relatively high in rhizospheric soil (Figure 4E,F). In contrast, $t x t A B$ expression was low in the DS variety (Figure 4E). 


\section{Gangneung}
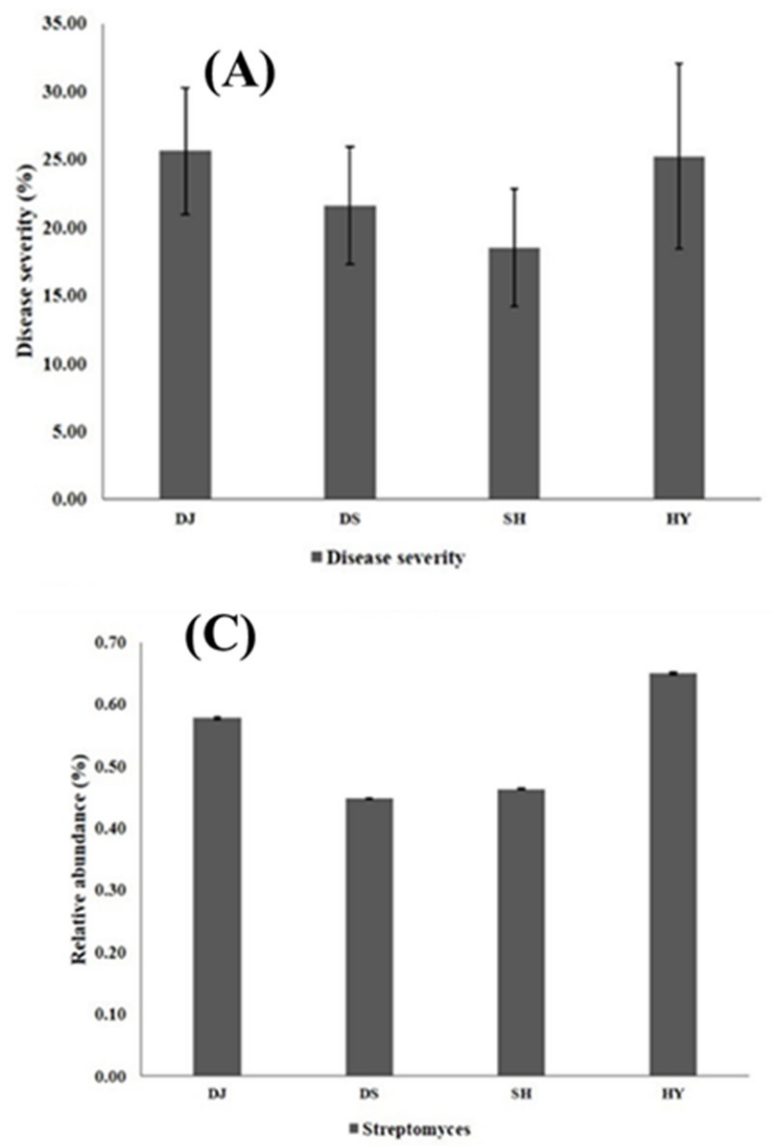

(E)

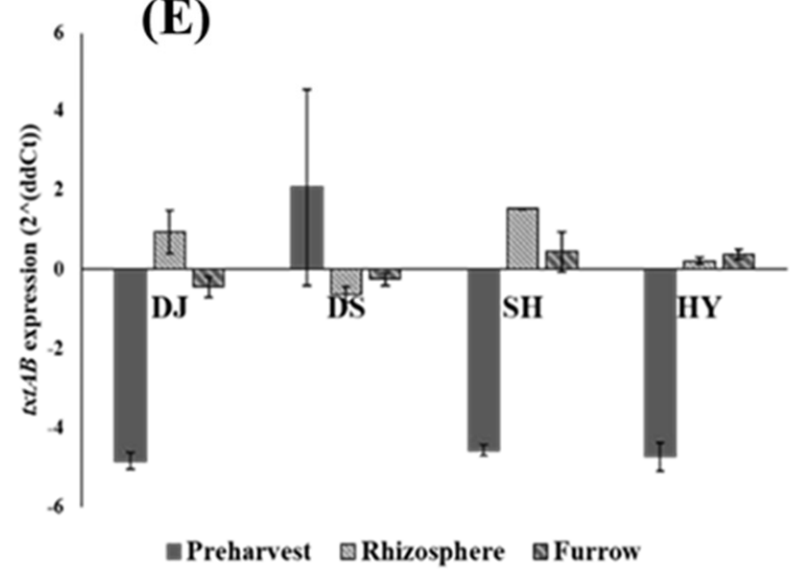

\section{Chuncheon}

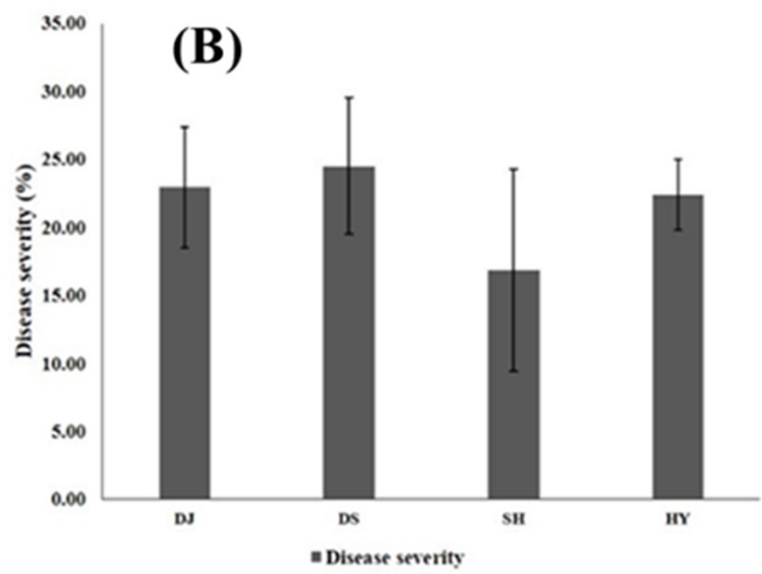

(D)
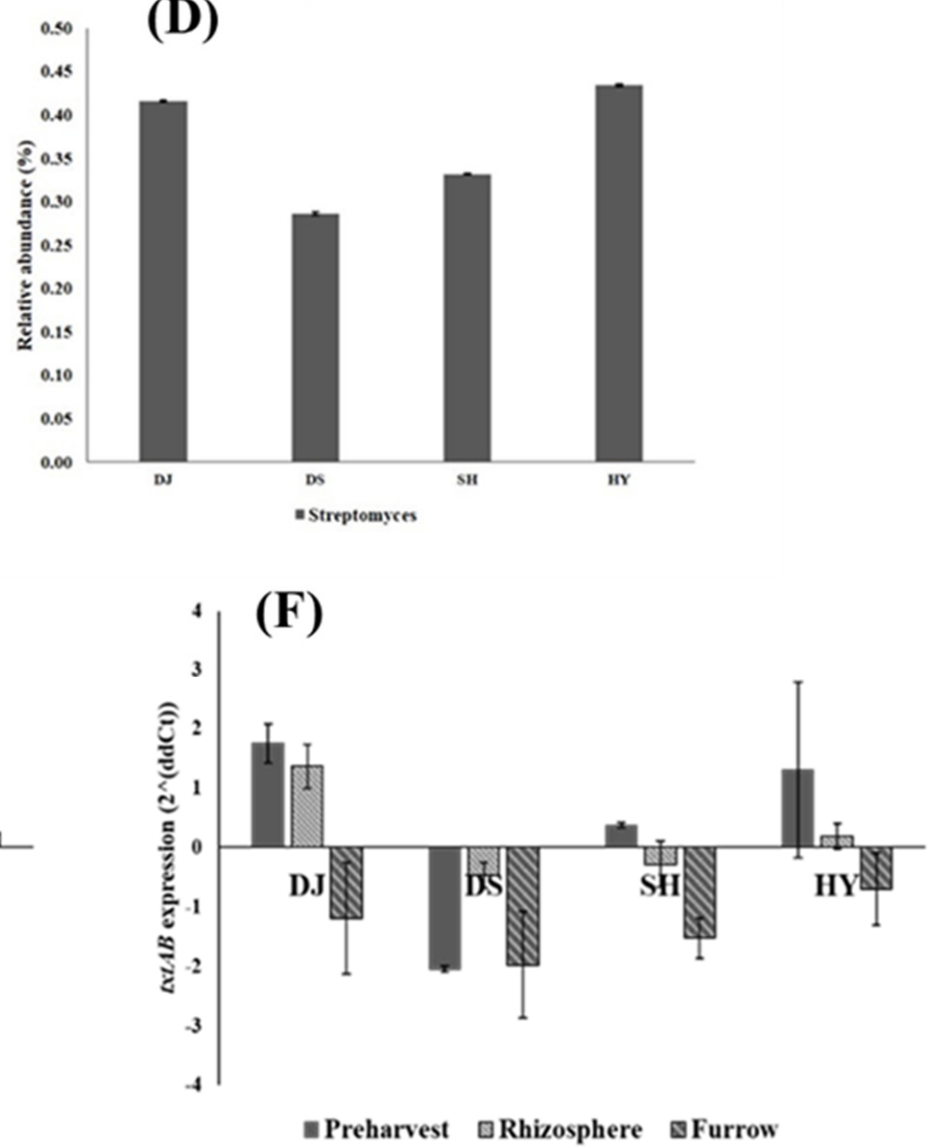

Figure 4. Relative abundance of Streptomyces spp. severity and txtAB expression. $(\mathbf{A}, \mathbf{B})$ indicated disease severity in Gangneung and Chuncheon; (C,D) relative abundance of Streptomyces spp. (E,F) showed kevels of gene expression of each varieties in Gangneung and Chuncheon. (DJ: Daeji, DS: Daeseo, SH: Seohong and HY: Haryoung). Note: Preharvest; before harvesting of potato. Rhizophere and furrow; spatial locations.

\subsection{Correlation between Streptomyces spp. and Other Bacterial Communities}

Correlation networking analysis showed that 51 taxon groups were correlated with Streptomyces spp. (Supplementary Figure S5). Among the 51 taxon groups. 14 were significantly correlated according to Spearman correlation (Table 2). Streptomyces spp. were found to be positively correlated with Acidobacteria, Chloroflexi, and Planctomycetes, and nega- 
tively correlated with Bacteroidetes, Patescibacteria, and Verrucomicrobia (Supplementary Figure S5).

Table 2. Correlation analysis of 14 different bacterial genus and their significant level using a Spearman correlation.

\begin{tabular}{cccc}
\hline Order/Genus & $\begin{array}{c}\text { R-Value } \\
(\boldsymbol{p}<\mathbf{0 . 0 5})\end{array}$ & Order/Genus & $\begin{array}{c}\text { R-Value } \\
(\boldsymbol{p}<\mathbf{0 . 0 5})\end{array}$ \\
\hline Bryobacter & 0.495 & Flavobacterium & -0.554 \\
SBR1031/uncultured bacterium & 0.514 & Sphingobacteriales/uncultured bacterium & -0.495 \\
Chloroflexales/Uncultured & 0.492 & Saccharimonadales/uncultured bacterium & -0.562 \\
Tepidisphaerales/Other & 0.471 & Massilla & -0.502 \\
Pseudolabrys & 0.484 & Cellvibrio & -0.667 \\
Sphingomonas & 0.541 & Pseudomonas & 0.576 \\
Other/Other & 0.551 & Chthoniobacter & 0.557 \\
\hline
\end{tabular}

\section{Discussion and Conclusions}

The growing interest in manipulating soil microbes to enhance plant health and productivity [39] indicates the importance of the soil microbiome. The common scab of potatoes causes huge losses in temperate countries worldwide [6]. The soil microbiome could be an effective tool to better understand and control the abundance of the pathogenic Streptomyces spp. bacteria. However, it is still not clear how bacterial communities change between preharvest, rhizosphere, furrow, and potato varieties in different geographical locations. Hence, this study was performed to evaluate changes in bacterial communities for four potato varieties from two spatial locations (rhizosphere and furrow) and different harvest times (pre- and postharvest) from two different geographical locations (Gangneung and Chuncheon). The results of this study showed that, in most cases, the bacterial communities were not similar among Gangneung and Chuncheon in postharvest (rhizosphere and furrow) (Figure 1). However, we observed slight similarities in the bacterial communities among the potato varieties in both locations (Figure 1A-F). In a previous study, changes in the diversity of bacterial communities were reported for cultivars [40]. In contrast, in this study the bacterial richness (Chao1), OTUs, and diversity (Shannon) were similar in the DJ, DS, and SH varieties in furrow soil in Gangneung (Supplementary Figure S4); however, diversity was not similar in furrow soil after harvest. This result suggests that the variations in bacterial communities are due to differences in the soil composition and abundance of root exudates [41]. Although some differences in Chao1, OTUs, and Shannon indices were observed among varieties (Supplementary Figure $\mathrm{S} 4 \mathrm{a}, \mathrm{b}$ ), there was a significant variation between pre-and postharvest interactions. Linked with this, variety was not a significant factor when describing the diversity (alpha and beta) of the bacterial community [41] according to PCoA Unifrac analysis (Figure 2). In previous studies, beta diversity of the bacterial community differed at different growth stages of various varieties [42], thus, it may be the time of sampling (pre-and postharvest) and spatial locations (rhizosphere and furrow), not the potato varieties, responsible for the differences in the diversity of the bacterial community in this study. Similar results were also observed in a previous study [41].

Soil microorganisms play a crucial role in the occurrence and prevention of plant diseases [23]. The pathogenicity and severity of common scab was determined using various methods. A precise study exploring the interlinked relationship between common scab and microbial communities has not yet been clearly reported.

We noticed variations in the chemical properties of preharvest and postharvest soils. Such variation in the chemical properties of the soil samples might be due to the changing environmental conditions, topography, and climate [43] during the preharvest and postharvest periods. The distribution of local and regional microclimates alters the pattern of temperature and precipitation [44], which is what we have accessed in our study by examining two different locations (Gangneung and Chuncheon) (Supplementary Table S1). 
Previous studies have reported that the abundance of phytopathogenic Streptomyces spp. was not the causative factor for the severity of common scab among potato varieties [41]. The rhizosphere is diversified by different microorganisms [45]. Various factors, such as competition and cooperation between microbes, improve their survival rate in changing environments [46]. Linked to this, in this study, Figure 4A,B also suggest that disease severity could be affected by some kind of interaction between virulence and non-virulence factors, rather than varieties. The important virulence factor of common scab is thaxotomin, which is encoded by $t x t A B$ genes through the process of non-ribosomal peptide synthetase [35]. Gene expression was determined by quantitative PCR (Figure 4C,D). This clearly suggests that, rather than varieties, harvest time might be a significant factor affecting Streptomyces spp. As the number of $t x t A B$ gene copies was higher in the geocaulosphere than in rhizospheric soil [23], the level of $t x t A B$ gene expression might be diverse (Figure $4 \mathrm{C}, \mathrm{D}$ ). In addition, when comparing the Streptomyces spp.-susceptible DJ variety to other varieties (DS, SH, and HY), it expressed higher relative abundance in soils from both locations (Gangneung and Chuncheon). Furthermore, Streptomyces spp. in both sites and their correlation with other bacterial genera (through correlation network analysis) (Supplementary Figure S5) also provide considerable evidence. The 14 most dominant bacterial genera were found to have significant relationships with Streptomyces spp. (Table 2). In contrast, Pseudomonas showed a negative correlation in this study. In previous studies, it was reported that $P$ seudomonas strains reduced common scab by interfering with the transcriptional expression of $t x t A$ and $t x t C$ genes in vitro and effectively reduced the symptoms of common scab in field conditions [21,47]. This statement may be related to the possibility of negatively correlated microbes inhibiting the common scab.

Bacterial diversity was analyzed using $\alpha$-diversity indices based on location, harvesting time, and variety (Supplementary Figure S4a,b). The results clearly indicate that diversity was not consistent among all factors. Similar results were reported in previous study [41]. The diversity of microbes in rhizospheric soil is determined by the type of crop cultivated [48] and the properties of crops. However, this study found no differences in microbial diversity between the varieties. Another factor shaping bacterial diversity is soil pH [49], carbon sources, nutrient composition [50,51], various climatic factors such as temperature [52] and precipitation [53].

Although the diversity of bacterial communities did not change between the varieties in time and spatial locations in this study, some differences were observed in alpha and dominant relative abundance of key bacterial phyla among the varieties. This study clearly indicates that bacterial community diversity is affected by time (pre- and postharvest), spatial location (rhizosphere and furrow), and geographical location (Gangneung and Chuncheon), rather than varieties. In addition, the relative abundance of Streptomyces spp. was higher in the susceptible DJ variety than in the other varieties (DS, SH, and HY). There is a possibility that synergistic or antagonistic interactions among the specific taxa and the common scab pathogen may have led to differences in the abundance of common scab pathogens. However, detailed insights are needed to correlate the specific bacterial genus interaction with common scab pathogens and different varieties (susceptible, semi-susceptible, tolerant, semi-tolerant), spatial locations, and in different geographical locations to determine the general trend in manipulating the soil microbiome in plant health.

Supplementary Materials: The following are available online at https:/ / www.mdpi.com/article/10 .3390/d13120659/s1, Figure S1: Details of soil sampling sites and its GPS (Global Positioning System) locations, Table S1: Average environmental conditions for a week to each locations (Gangneung and Chuncheon) during pre and post harvesting of potato, Figure S2: Dominant bacterial phylum according to sites, spatial locations and harvest time, Figure S3: Bacterial diversity indices in Gangneung and Chuncheon, Figure S4: Bacterial diversity indices obtained after metagenomics sequencing from different varieties of potato cultivated soils in two different sites (Gangneung and Chuncheon) and spatial locations (rhizosphere and furrow), Correlation network analysis between Streptomyces spp. 
and other bacterial communities. The network was undirected and binary network as only microbial communities (color node) related with Streptomyces spp. (black node).

Author Contributions: Conceptualization, D.H.P.; Designed the experiments, D.H.P. and G.S.L.; Methodology and experiment, G.S.L. and M.A.; software analysis and data interpretation, G.S.L. and M.A.; resources. K.S.H. and K.-S.H.; Manuscript preparation, M.A. and G.S.L.; review and editing, D.H.P.; funding acquisition, J.E.Y. and H.S.K. All authors have read and agreed to the published version of the manuscript.

Funding: This research was funded by Korea Ministry of Environment, with the strategic EcoSSSoil Project, KEITI (Korea Environmental Industry and Technology Institute), Korea (Grant No. 2019002820004).

Institutional Review Board Statement: Not applicable.

Informed Consent Statement: Not applicable.

Data Availability Statement: The data presented in this study are available on request from the corresponding author.

Acknowledgments: This research was supported in part by Research Grant from Kangwon National University in 2021 and by the Korea Ministry of Environment, with the strategic EcoSSSoil Project, KEITI (Korea Environmental Industry and Technology Institute), Korea (Grant No. 2019002820004).

Conflicts of Interest: The authors declare no conflict of interest.

\section{References}

1. FAOSTAT. Food and Agriculture Organization of the United Nations. Statistic Division. Available online: http://www.fao.org/ faostat/en/\#data/QC/visualize (accessed on 25 September 2021).

2. Zhang, H.; Gao, Z.; Shi, A.; Fang, S. Soil bacterial diversity and its relationship with soil $\mathrm{CO}_{2}$ and mineral composition: A case study of the Laieu experimental site. Int. J. Environ. Res. Public Health 2020, 17, 5699. [CrossRef]

3. Correa de Souza, R.S.; Armanhi, J.S.L.; Arruda, P. From microbiome to traits: Designing synthetic microbial communities for improved crop resiliency. Front. Plant Sci. 2020, 11, 1179. [CrossRef]

4. Zhang, L.; Zhang, J.; Wei, Y.; Liu, G.; Zeng, H.; Shi, H. Microbiome-wide association studies reveal correlations between the structure and metabolism of the rhizosphere microbiome and disease resistance in cassava. Plant Biotechnol. J. 2021, 19, 689-701. [CrossRef]

5. Wei, Z.; Gu, Y.; Friman, V.P.; Kowalchuk, G.A.; Xu, Y.; Shen, Q.; Jousset, A. Initial soil microbiome composition and functioning predetermine future plant health. Sci. Adv. 2019, 5, eaaw0759. [CrossRef] [PubMed]

6. Loria, R.; Kers, J.; Joshi, M. Evolution of plant pathogenicity in Streptomyces. Annu. Rev. Phytopathol. 2006, 44, 469-487. [CrossRef]

7. Hill, J.; Lazarovits, G. A mail survey of growers to estimate potato common scab prevalence and economic loss in Canada. Can. J. Plant Pathol. 2005, 27, 46-52. [CrossRef]

8. Dees, M.W.; Wanner, L.A. In search of better management of potato common scab. Potato Res. 2012, 55, 249-268. [CrossRef]

9. Peters, R.D.; Sturz, A.V.; Carter, M.R.; Sanderson, J.B. Influence of crop rotation and conservation tillage practices on the severity of soil-borne potato diseases in temperate humid agriculture. Can. J. Soil Sci. 2004, 84, 397-402. [CrossRef]

10. Haynes, K.G.; Wanner, L.A.; Thill, C.A.; Bradeen, J.M.; Miller, J.; Novy, R.G.; Vinyard, B. Common scab trials of potato varieties and advanced selections at three US locations. Ann. J. Potato Res. 2010, 87, 261-276. [CrossRef]

11. Lapwood, D.H.; Wellings, L.W.; Rosser, W.R. The control common scab of potatoes by irrigation. Ann. Appl. Biol. 1970, 66, 397-405. [CrossRef]

12. Larkin, R.P.; Honeycutt, C.W.; Griffin, T.S.; Olanya, O.M.; Halloran, J.M.; He, Z. Effects of different potato cropping system approaches and water management on soil borne disease and soil microbial communities. Phytopathology 2011, 101, 58-67. [CrossRef] [PubMed]

13. Scholte, K.; Labruyère, R.E. Netted scab: A new name for an old disease in Europe. Potato Res. 1985, 28, 443-448. [CrossRef]

14. Lacey, M.J.; Wilson, C.R. Relationship of common scab incidence of potatoes grown in Tasmanian ferrosol soils with pH, exchangeable cations and other chemical properties of those soils. J. Phytopathol. 2001, 149, 679-683. [CrossRef]

15. Lambert, D.H.; Loria, R. Streptomyces acidiscabies sp. nov. Int. J. Syst. Evol. Microbiol. 1989, 39, 393-396. [CrossRef]

16. Lindholm, P.; Kortemaa, H.; Kokkola, M.; Haahtela, K.; Salkinoja-Salonen, M.; Valkonen, J.P.T. Streptomyces spp. isolated from potato scab lesions under Nordic conditions in Finland. Plant Dis. 1997, 81, 1317-1322. [CrossRef]

17. Al-Mughrabi, K.I.; Vikram, A.; Poirier, R.; Jayasuriya, K.; Moreau, G. Management of common scab of potato in the field using biopesticides, fungicides, soil additives, or soil fumigants. Biocontrol Sci. Technol. 2016, 26, 125-135. [CrossRef]

18. Larkin, R.P.; Griffin, T.S.; Honeycutt, C.W. Rotation and cover crop effects on soil borne potato disease, tuber yield, and soil microbial communities. Plant Dis. 2010, 94, 1491-1502. [CrossRef] 
19. Wiggins, B.E.; Kinkel, L.L. Green manures and crop sequences influence alfalfa root rot and pathogen inhibitory activity among soil-borne streptomycetes. Plant Soil 2005, 268, 271-283. [CrossRef]

20. Hiltunen, L.H.; Weckman, A.; Ylhäinen, A.; Rita, H.; Richter, E.; Valkonen, J.P.T. Responses of potato cultivars to the common scab pathogens, Streptomyces scabies and S. turgidiscabies. Ann. Appl. Biol. 2005, 146, 395-403. [CrossRef]

21. St-Onge, R.; Gadkar, V.J.; Arseneault, T.; Goyer, C.; Filion, M. The ability of Pseudomonas sp. LBUM 223 to produce phenazine1-carboxylic acid affects the growth of Streptomyces scabies, the expression of thaxtomin biosynthesis genes and the biological control potential against common scab of potato. FEMS Microbial. Ecol. 2011, 75, 173-183. [CrossRef]

22. Chin, A.; Woeng, T.F.C.; Bloemberg, G.V.; van der Drift, K.M.G.M.; Schripsema, J.; Kroon, B.; Keel, C.; Balser, P.A.H.M.; Tichy, H.V.; de Brujin, F.K.; et al. Biocontrol by phenazine-1-carboxamide-producing Pseudomonas chlorophis PCL1391 of tomato root caused by Fusarium oxysporum f.sp. radicis-lycopersici. Mol. Plant.-Microbe Interact. 1998, 11, 1069-1077. [CrossRef]

23. Shi, W.; Li, M.; Wei, G.; Tian, R.; Li, C.; Wang, B.; Gao, Z. The occurrence of potato common scab correlates with the community composition and function of the geocaulosphere soil microbiome. Microbiome 2019, 7, 1-18. [CrossRef]

24. Wang, R.; Zhang, H.; Sun, L.; Qi, G.; Chen, S.; Zhao, X. Microbial community composition is related to soil biological and chemical properties and bacterial wilt outbreak. Sci. Rep. 2017, 7, 1-10.

25. Mendes, R.; Kruijt, M.; De Bruijn, I.; Dekkers, E.; van der Voort, M.; Schneider, J.H.; Raaijmakers, J.M. Deciphering the rhizosphere microbiome for disease suppressive bacteria. Science 2011, 332, 1097-1100. [CrossRef]

26. Romaniuk, R.; Giuffre, L.; Costantini, A.; Nannipiere, P. Assessment of soil microbial diversity measurements as indicators of soil functioning in organic and conventional horticulture systems. Ecol. Indic. 2011, 11, 1345-1353. [CrossRef]

27. Bastida, F.; Torres, I.F.; Moreno, J.L.; Baldrian, P.; Ondono, S.; Ruiz-Navarro, A.; Jehmlich, N. The active microbial diversity drives ecosystem multifunctionality and is physiologically related to carbon availability in Mediterranean semi-arid soils. Mol. Ecol. 2016, 25, 4660-4673. [CrossRef] [PubMed]

28. Kumar, D.; Jamdagni, P.; Goyal, K. Recent trends in characterization of microbial Diversity from Environment. Acta Agric. Serbica 2012, 17, 31-46.

29. Lara-Victoriano, F.; Castillo-Reyes, F.; Flores-Gallegos, C.; Aguilar, C.N.; Rodriguez-Herrera, R. Metagenomics in plant pathology. In Phytopathology in the Omics Era; Research Signpost: Trivandrum, India, 2011; ISBN 978-81-308-0438-5.

30. Piombo, E.; Abdelfattah, A.; Droby, S.; Wisniewski, M.; Spadaro, D.; Schena, L. Metagenomics approaches for the detection and surveillance of emerging and recurrent plant pathogens. Microorganisms 2021, 9, 188. [CrossRef] [PubMed]

31. Fierer, N.; Jackson, R.B. The diversity and biogeography of soil bacterial communities. Proc. Natl. Acad. Sci. USA 2006, 103, 626-631. [CrossRef] [PubMed]

32. Bates, S.T.; Clemente, J.C.; Flores, G.E.; Walters, W.A.; Parfrey, L.W.; Knight, R.; Fierer, N. Global biogeography of highly diverse protistan communities in soil. ISME J. 2013, 7, 652-659. [CrossRef]

33. Igalavithana, A.D.; Lee, S.S.; Niazi, N.K.; Lee, Y.H.; Kim, K.H.; Park, J.H.; Moon, D.H.; Ok, Y.S. Assessment of soil health in urban agriculture: Soil enzymes and microbial properties. Sustainability 2017, 9, 310. [CrossRef]

34. Bates, S.T.; Berg-Lyons, D.; Caporaso, J.G.; Walters, W.A.; Knight, R.; Fierer, N. Examining the global distribution of dominant archael populations in soil. ISME J. 2011, 5, 908-917. [CrossRef]

35. Sagova-Mareckova, M.; Daniel, O.; Omelka, M.; Kristufek, V.; Divis, J.; Kopeck, J. Determination of factors associated with natural soil suppressivity to potato common scab. PLOS ONE 2015, 10, e0116291.

36. Rognes, T.; Flouri, T.; Nichols, B.; Quince, C.; Mahé, F. VSEARCH: A versatile open source tool for metagenomics. Peer J. 2016, 4 , e2584. [CrossRef] [PubMed]

37. Jiang, J.; Song, Z.; Yang, X.; Mao, Z.; Nie, X.; Guo, H.; Peng, X. Microbial community analysis of apple rhizosphere around Bohai Gulf. Sci. Rep. 2017, 7, 8918. [CrossRef] [PubMed]

38. Sokal, R.R.; Michener, C.D. A statistical method for evaluating systematic relationships. Univ. Kans. Sci. Bull. 1958, 38, 1409-1438.

39. Van Elsas, J.D.; Chiurazzi, M.; Mallon, C.A.; Elhottova, D.; Kristufek, V.; Salles, J.F. Microbial diversity determines the invasion of soil by a bacterial pathogen. Proc. Natl. Acad. Sci. USA 2012, 109, 1159-1164. [CrossRef]

40. Berg, G.; Smalla, K. Plant species and soil type cooperatively shape the structure and function of microbial communities in the rhizosphere. FEMS Microbial. Ecol. 2009, 68, 1-13. [CrossRef]

41. Nahar, K.; Floc'h, J.B.; Goyer, C.; Zebarth, B.J.; Whitney, S. Diversity of Soil Bacterial Community Is Influenced by Spatial Location and Time but Not Potato Cultivar. Phytobiomes J. 2020, 4, 225-238. [CrossRef]

42. Inceiglu, O.; Ai-Soud, W.A.; Salles, J.F.; Semenov, A.V.; van Elsas, J.D. Comparative analysis of bacterial communities in a potato field as determined by pyrosequencing. PLoS ONE 2011, 6, e23321.

43. Liu, R.; Pan, Y.; Bao, H.; Liang, S.; Jiang, Y.; Yu, H.; Nong, J.; Huang, W. Variations in soil physico-chemical properties along slope position gradient in secondary vegetation of the hilly region, Guilin, Southwest China. Sustainability 2020, 12, 1303. [CrossRef]

44. Yimer, F.; Ledin, S.; Abdelkadir, A. Soil organic carbon and total nitrogen stock as affected by topographic aspect and vegetation in the Bale Mountains, Ethiopia. Geoderma 2006, 135, 335-344. [CrossRef]

45. Hartmann, A.; Schmid, M.; Van Tuinen, D.; Berg, G. Plant-driven selection of microbes. Plant Soil. 2009, 321, 235-257. [CrossRef]

46. Essarioui, A.; LeBlanc, N.; Kistler, H.C.; Kinkel, L.L. Plant community richness mediates inhibitory interactions and resource competition between Streptomyces and Fusarium populations in the rhizosphere. Microb. Ecol. 2017, 74, 157-167. [CrossRef] [PubMed] 
47. Arseneault, T.; Goyer, C.; Filion, M. Pseudomonas fluorescens LBUM223 increases potato yield and reduces common scab symptoms in the field. Phytopathology 2015, 105, 1311-1317. [CrossRef] [PubMed]

48. Marschner, P.; Yang, C.H.; Lieberei, R.; Crowley, D.E. Soil and plant specific effects on bacterial community composition in the rhizosphere. Soil Biol. Biochem. 2001, 33, 1437-1445. [CrossRef]

49. Lauber, C.L.; Hamady, M.; Knight, R.; Fierer, N. Pyrosequencing-based assessment of soil pH as a predictor of soil bacterial community structure at the continental scale. Appl. Environ. Microbiol. 2009, 75, 5111-5120. [CrossRef]

50. Waldrop, M.P.; Zak, D.R.; Blackwood, C.B.; Curtis, C.D.; Tilman, D. Resource availability controls fungal diversity across a plant diversity gradient. Ecol. Lett. 2006, 10, 1127-1135. [CrossRef]

51. Delgado-Baquerizo, M.; Reich, P.B.; Khachane, A.N.; Campbell, C.D.; Thomas, N.; Freitag, T.E.; Singh, B.K. It is elemental: Soil nutrient stoichiometry drives bacterial diversity. Environ. Microbiol. 2017, 19, 1176-1188. [CrossRef]

52. Zhou, J.; Deng, Y.; Shen, L.; Wen, C.; Yan, Q.; Ning, D.; Voordeckers, J.W. Temperature mediates continental-scale diversity of microbes in forest soils. Nat. Commun. 2016, 7, 1-10. [CrossRef]

53. Maestre, F.T.; Delgado-Baquerizo, M.; Jeffries, T.C.; Eldridge, D.J.; Ochoa, V.; Gozalo, B.; Bowker, M.A. Increasing aridity reduces soil microbial diversity and abundance in global drylands. Proc. Natl. Acad. Sci. USA 2015, 112, 15684-15689. [CrossRef] [PubMed] 